In the article, the author analyses three plays by Simona Semenic that were published in the book can you hear me? (2017). At first sight, the three pieces appear to be written in Semenič's now-familiar writing style with no punctuation marks or upper-case initials and no apparent division between dialogues and stage directions. Content-wise, however, the three plays differ significantly from the bulk of the playwright's opus as they represent autobiographical texts which once again establish the character and more or less distinct dramatic action. The article focuses on two questions: Are these still no-longer-dramatic texts? And, what is the status of representation and performativity in them? By analysing the formal and content properties of the three texts, more precisely, through an analysis of the drama character, the relationship between dialogue and monologue and dramatic action, the author shows that indeed these texts establish recognisable dramatic characters and relatively strong dramatic action. In this, they move away from no-longerdramatic texts as defined by Gerda Poschmann, even though their legacy is still very much present, e.g., in the fragmented writing style.

Keywords: Simona Semenič, can you hear me?, no-longer-dramatic text, dramatic text, Birgit Haas

Gašper Troha graduated from the Department of Comparative Literature and Literary Theory of the Faculty of Arts and the Academy of Music, both of the University of Ljubljana. In 2007, he received his PhD with the dissertation "Artikulacija odnosa do oblasti v slovenski drami 1943-1990" (The Articulation of the Relationship to Authority in Slovenian Drama 1943-1990). His research focuses on sociology of literature, especially concerning the questions of the contemporary world and Slovenian drama and theatre. He works parttime at the Faculty of Arts and at the Academy of Theatre, Film, Radio and Television of the University of Ljubljana. He has contributed to numerous national and foreign scientific journals and edited several scientific monographs, among them, History and its Literary Genres, Literarni modernizem v »svinčenih « letih (Literary Modernism in the Years of Lead) and Lojze Kovačič: življenje in delo (Lojze Kovačič: Life and Work). His recent publications include a book on cultural opposition and Slovene dramatic literature entitled Ujetniki svobode (Prisoners of Freedom). 


\section{can you hear me? by Simona Semenič and the question of no-longer-dramatic writing ${ }^{1}$}

Gašper Troha

University of Ljubljana, Faculty of Arts, Academy of Theatre, Radio, Film and Television

\section{Introduction}

Simona Semenič is probably the most provocative contemporary Slovenian dramatist. A characteristic of her work is her constant experimentation with form. Usually, her work is designated as no-longer-dramatic writing (see Leskovšek; Toporišič "(Ne več) dramski"). In 2017, the organisation Zrakogled published her book Me slišiš in Slovenian, which was translated into English and published in 2019 by Integrali Cultural Association as can you hear me?. The book presents three of her autobiographical performances: Jaz, žrtev (I, victim, 2007); še me dej (do me twice, 2009); and drugič (the second time, 2014). Semenič also performed each of them in their respective year of creation.

At first sight, the three pieces appear to be written in Semenič's now-familiar writing style with no punctuation marks or upper-case initials and no apparent division between dialogue and stage directions. In her text, the author continuously polemicises with the audience; she takes them as co-creators of the performance and requires them to take on an active role. This demand could be considered to mark a shift from representation to the presence characteristic of postdramatic theatre (Lehmann) and no-longer-dramatic texts (Poschmann). However, as the author herself explains in the book's introduction: "These are autobiographical texts, in which - as I figured out after reading them all again - I mostly deal with authority. Using personal incidents, these three texts more or less curse the system in which we're currently living" (10). The latter probably indicates a deviation from the author's other writings, which steers us towards the following two questions: Are these still no-longer-dramatic texts? What is the status of representation and presence in these texts?

1 The article was written within the research programme Theatre and Interart Studies P6-0376, which is financially supported by the Slovenian Research Agency. 
Some researchers have already noticed that in the opus of Simona Semenič, the three pieces in question stray from the pattern. Thus, Ivana Zajc, in her research of monodramatic and autobiographical elements in Simona Semenič's plays, uses stylometric analysis to reveal that the three plays in question make up a special subgroup which, according to the proportion of monologic elements, "differ from the rest, while the feast could be listed among them, it is, however, itself the most distant from all of the other texts considered" (86).

In his essay on dramatic writing after postdramatic theatre, Tomaž Toporišič also highlights the fact that the plays by Simona Semenič surpass no-longer-dramatic writing and produce powerful dramatic effects.

She persistently reshapes the dialogic form accompanied with heterogeneous textual strategies: from stage directions to descriptions that are closer to the novel and prose, to the narrative, essayistic, theoretical, and other techniques which remind the audience that what they are reading or observing is no longer a realistic dialogue. However, she produces explicitly dramatic effects that Haas would probably designate as "dramatically dramatic". ("Dramske" 114)

To explore how in can you hear me? Simona Semenič shifts between post-dramatic and dramatic writing and what is the implication of that for the question of representation and presence, or rather why this type of writing is so much different from the plays that are based on distinguishing between dialogue and stage directions, on dramatic action, on the thickening of the plot, etc., while at the same time remaining very much dramatic and relevant, we will refer to Birgit Haas's idea about again-dramatic texts and, of course, a careful analysis of the selected plays by Simona Semenič.

\section{No-longer-dramatic and dramatic writing for theatre}

In her preface to Tri drame (Three Plays) by Simona Semenič, Nika Leskovšek aptly articulates the researcher's predicament when categorising the texts in question. In this, she first establishes that Simona Semenič's works deviate from Peter Szondi's notion of absolute drama and introduce an entire series of episation procedures that might, at first sight, seem to position her in the field of post-dramatic or even nolonger-dramatic writing. However, such classification is by no means straightforward. Leskovšek here poses the question

whether the effect of her drama can be reduced to linguistic effects and the combination of linguistic strata, the effects of intertextuality and self-reference, or rather to the careful self-reflective construction of the text by careful dosing and luring the spectator to extract the effect of the story / the answer is nuanced and complex, it varies from 
play to play, and again it depends on the ratio between stage directions and lines, their

arrangement, their meaning and the orientation of the narrative (122).

Since the considered terms such as postdramatic theatre, aesthetics of the performative, no-longer-dramatic text, rhapsodic drive of theatre text are quite well established in the Slovenian theatre landscape, we will only highlight them briefly here for the needs of the discussion. The essence of all these shifts, aptly described by Tomaž Toporišič in his paper "(No Longer) Dramatic Text for Theater and Postdramatic Theatre", appears to lie in the paradigmatic shift that took place in theatre during the late 1960s. It is in this period that both Hans Thies Lehmann (Cf. Postdramatic Theatre) and Erika Fischer-Lichte (The Transformative Power of Performance, A New Aesthetics) locate the origins of contemporary perspectives of theatre stagings. Lehmann noticed an ongoing process of dethroning the text for theatre at work in contemporary theatre. Thus, the text became merely one of the elements of theatre among many others that build up a theatre event as something that happens between performers and spectators of each individual performance. The text thus becomes radically open, disposable and, first and foremost, no longer referential but somewhat self-reflective. As Toporišič lucidly summarises:

To Lehmann, however, postdramatic theatre as the liberation from the three-star model does not mean a theatre that lacks a connection beyond drama. It is but the process of decomposition, dismantling and deconstruction inside drama itself. He sees the future of theatre after drama as the future of theatre beyond the primacy of the dramatic author or rather as theatre after a chain of crises of the dramatic author, as successive stages of selfreflection, decomposition and separation of dramatic theatre. ("(Ne več) dramski" 182)

Erika Fischer-Lichte detects the same process. However, she focuses on theatre performance. After the so-called performative turn, the latter started to deal with the autopoietic feedback loop, or more specifically, how individual elements of the performance affect this loop. Thus, the main focus is no longer on the text for theatre that needs to be put on stage and is probably supposed to reflect some theme/action that is, of course, its reference. The emphasis is now on establishing an event, the circumstances in which the co-existence of actors and spectators becomes essential for something to happen and thus allow for the emergence of meanings.

Just like Müller, Jelinek also develops a new theatricality in her texts that differs from the theatricality of dramatic plays. This is no longer dramatic theatricality aimed at creating possible referents of their signs, but rather, an analytical theatricality that is selfreflective and no longer aimed at stage-fictive presentation. Instead, it is established as an interaction - Fischer-Lichte would call this the performative act of the performance as the interaction between performers and spectators, the characteristic feature of which is the autopoietic feedback loop which provokes and integrates emergence between actors and spectators. (Toporišič, "(Ne več) dramski" 184) 
Gerda Poschmann designated texts that radically deconstruct the dramatic form and introduce epic as well as lyrical elements into it as no-longer-dramatic; Jean Pierre Sarrazac talks about the notion of rhapsody. These are texts that widen their possibilities and construct new forms through their apparent deconstruction. "Theatre, drama that looked towards the novel, poem, or essay in order to liberate itself again and again from that which has always been its curse: its status of 'canonic' art" (Sarrazac 24).

However, an in-depth discussion of the crisis of drama writing in the last sixty years is not our intention here. Instead, it is to track down further developments that Birgit Haas has detected in recent German drama with Dea Loher as one of its prime representatives. While the experience of the no-longer-dramatic and the deconstruction of form that comes with it is still characteristic of these authors and their plays, they also reintroduce the story, the subject, narration and external reference into it. Furthermore, it was precisely this type of drama that introduced a solid, fresh wave of political theatre in Germany. But what are the procedures that Dea Loher uses to achieve this? "Despite the defamiliarised Verfremdungseffekt, however, she neither subscribes to the postmodern decentering of the subject nor to the end of the metanarratives. Instead, Loher draws on Walter Benjamin's revolutionary Marxist aesthetic that he established in order to retain a human element in the arts, a human element that would resist the technical innovations of his time" $(74,75)$.

This type of drama is therefore characterised by the reintroduction of a more or less discernible character, the agent of both speech and action and, more to the point, their own world view. At the same time, the latter also builds up a discernible story of the entire drama. Of course, this does not imply a return to some kind of pseudorealism, but rather an extremely fragmented narrative marked by the insights of postmodernism. As Birgit Haas puts it, the author

Loher deliberately causes a feeling of uncertainty, mainly due to the mixture of private and public political discourses. [...] Her work is a creative and productive revival of the Brechtian theatre in the context of the post-postmodern age, an age in which human beings have again reclaimed the theatrical space. [...] As a consequence, Loher's theatre is a theatre of empowerment, a politically engaged theatre that does not leave the bewildered spectator in front of a destroyed history. (85)

So what are the distinctive characteristics that mark the first and the second form of writing for theatre? Can we draw a clear line between them, or do they overlap to a certain degree? It appears that what we are dealing with here is another example of the cycle of crisis and renaissance or, as Toporišič puts it, of being trapped between the terms "to end" and "to begin", albeit one that, in our opinion, plays out within the question of referentiality. While no-longer-dramatic texts invest into the 
construction of emergent meaning that depends on each particular situation and its participants (both actors and spectators) and thus cannot be anything else but the training of the gaze in which "the broken thread between perception and the personal experience becomes visible" (Lehmann 308), dramatic theatre texts, on the other hand, do establish distinguishable characters and stories with referents, albeit very fragmentary ones. The latter also allows them to reestablish concrete social criticism or the criticism of particular social relations and attitudes.

In the words of Richard McClelland, who explores the co-existence of both notions in contemporary German drama in his discussion:

She describes the work of playwrights such as Martin Crimp, Elfriede Jelinek, Heiner Müller and Sarah Kane as "open" or "writerly" texts [...] in the sense that they require the spectators to become active co-writers of the (performance) text. The spectators are no longer just filling in the predictable gaps in dramatic narrative but are asked to become active witnesses who reflect on their own meaning-making and who are also willing to tolerate gaps and suspend the assignment of meaning. (4)

There are two essential distinguishing characteristics of dramatic texts for theatre.

First, the playwright reasserts the position of the subject at the centre of dramatic representation. Second, these texts engage with postmodern and modernist legacies by combining a quasi-realist exploration of lived experience with a postmodern distrust of reality as a singular entity. (Ibid.)

So how is this passing between no-longer-dramatic and dramatic reflected in the three texts by Simona Semenič?

\section{Dramatic and postdramatic in can you hear me?}

can you hear me? is a trilogy of plays that, to a certain extent, represent a curiosity in Simona Semenič's opus. The author herself is well aware of this fact as she says in the introduction to her book: "These texts, however, are of a different nature in both contents, written for me to perform myself, and form, which is dramatic or not" (can you 11).

The author thus senses that the plays in question represent a special kind of text which hangs somewhere in-between the dramatic and the no-longer-dramatic. The least one could say is that their status is not so readily determinable as in the case of her other works. To gain a clearer insight into the content and form of these three plays, we intend to approach them from three perspectives: 1) from the position 
of the author, or rather, the dramatis persona; 2) from the dramatic form, which encompasses the form of the discourse (the ratio of stage directions to spoken lines, dialogue-monologue), the relationship to the reader/spectator and their position in the text itself; 3 ) from the story or dramatic action. These determinants seem crucial for distinguishing between no-longer-dramatic and dramatic texts for theatre, as argued above.

The first play entitled $I$, victim is the most consistently autobiographical and monologic of the three. What we mean by this is the fact that in it, the author is, for the bulk of the time, talking about herself in a monologue lasting throughout the play. The fact that the text is intended as a play can only be inferred from the introductory and closing stage directions, which are written in cursive.

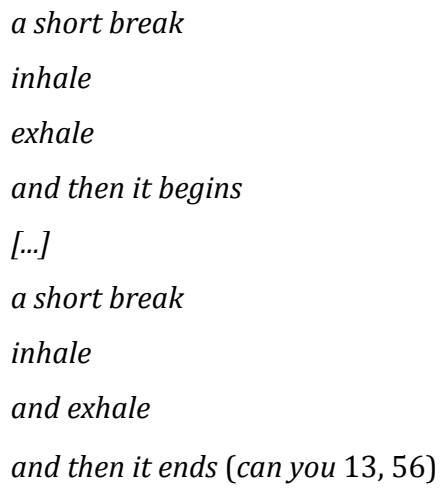

In this sense, the published version is a bit different, as the author added an accompanying text which is not just a preface at the beginning. Instead, it expands throughout the entire body of the text so that she can explain the circumstances of the creation of the plays as she goes along. These explanations represent a meta-text and introduce the figure of a narrator and a mediating level into the communication scheme. In other words, this establishes a decisive moment of episation that helps to make the author's point come across to the reader even more poignantly, as it reveals her autopoietics and philosophy of life. However, it also explains the making and future destiny of all three plays. The first one of these commentaries goes as follows: "Here, I have to interrupt. Just to tell you that Vesna is the very Vesna who, in some epilepsy free dimension, designated me for a lab coat and a test tube and the Jožef Stefan Institute. I'll get to the epilepsy. Read on" (can you 15).

The next play, do me twice, already diverges from this model. It is still about Simona Semenič, a.k.a., the author herself. However, the main focus of her interest here is on the author as a character embedded into the processes of contemporary theatre production on the so-called independent scene, revealing to us all the intricacies of funding and other bureaucratic procedures. The whole play is "one of those 
iwontreturnthemoney shows" (can you, 62), those performances that have received funding and thus need to be realised to justify the costs, even though the project is not even close to being properly elaborated and carried out the way its creators have initially envisioned it. Here there are many more stage directions describing the action. The author uses them to reflect on the relationship between the stage and the audience. Furthermore, here we can also see the author directly addressing the spectator or rather, putting herself into their shoes, a device she also used in her later plays (e.g., we, the european corpses). The author thus, at the same time, functions as a character, author/director and the one who entices the reader/spectator to enter the play and co-create it.

dear valued audience, while you're arriving, i'm

watching you

I see you, before you see me

i'm sitting by the window, the box office of the

theatre

$[\ldots]$

i smile at you

i'm a little impish

hi hi hi ha ha ha

it feels good, doesn't it feel good

i'm here

for you, highly valued audience (can you 59,60)

This way, she is directly persuading them to be active and to choose to participate in the event:

i wait if you decide to leave

if there's a provocateur inside you that would do it

but i don't want you to go

even though, yes, $i$ accept all the consequences

of my impish games

because - as i've said - $i$ don't want to return the

money

and here I smile at you impishly (can you 65)

In the end, the spectator/reader becomes part of the theatre event. 
while i'm bringing you the tripe i'm printing the

text

while you're eating tripe i'm placing the text in

your hands

text that is at the same time the programme and

the flier, at the end, look

you look at me, what about this

well, read, ok, why are you looking at me

look at the text, not at me

this is a part of the show, that now you eat tripe

in peace and read the text in peace (can you 98)

This inclusion of the reader enables the author to introduce dialogue. However, it is no longer a dialogue between characters but between the stage and the hall. The autopoietic feedback loop that is, in any case, a characteristic of any theatre event is directly addressed here. The text reflects on it, attempts to regulate it or at least point out some of its constituent elements (e.g., addressing the audience, pointing out their emotions, their role in the performance). This participation on the side of the spectator is not completely arbitrary. As Katja Čičigoj notes, indeed, it is to a large degree directed by the author: "The danger of arbitrary meaning is thus replaced by a pragmatic partial determination of the effect: intratextual directing of the situation in which the spectator is pushed into the experience of the zones of indeterminacy of the final effect of the event" (65).

Through this gesture, Simona Semenič, as a character, becomes more solid or rather more clearly outlined and unified. Her coherence is assured first and foremost because the nature of the play in question is autobiographical. Thus, the author's biography represents the external reference that defines this drama character and provides it with a context. Besides, it is about directing the spectator's participation. The possibilities of their participation are limited and anticipated, which narrows down the number of possible interpretations. This element brings us closer to the notion of dramatic text. This aspect, however, is only one of this development. Namely, this way, the same drama character also becomes more fragmented, as questions about the nature of the performance, the relationship between actor and spectator, etc., become attached to the autobiographical narrative or action. Additionally, the announcement of other actresses that are supposed to appear also enters the fictive world of the play, even though this ultimately does not take place: "In addition to myself, three other actresses play me - medea novak, lara jankovič and damjana černe" (can you 61). 
In the third play from can you hear me?, entitled, the second time, which premièred on 12 December 2004, in Club Gromka, it is the very beginning that is most significant, as this is the only play of the three in which the time and place of the action and a list of characters are stated. Under dramatis personae we can read: simona semenič, You. This dialogue partner that already formed in do me twice under the address of valued audience is here listed as a proper character. The reader/spectator is thus assigned their own place, their role in the play. Later in the play, we can see a radicalisation of the procedures already described in the case of do me twice. The author places herself into different roles ranging from a character telling us their story in a monologue to the dramatist reflecting on dramatic situations, directing the action, wondering about the audience's reactions or even predicting or demanding them.

dramatis persona simona semenič is entering

$i$ would like to imagine that $i$ enter graciously

and that everything becomes silent when $i$ enter

i'd like to imagine that the air thickens and time

stops, when i graciously step in front of you

but fuck it

i'm beyond exhausted, i've barely slept,

rehearsed all day and ran for 45 minutes (can you 101, 102)

The active participation of the spectators is first expressed merely as a desire: "maybe You step up onto the stage and maybe / You approach me and maybe You help me roll up / my sleeve and set the blood pressure measuring / machine" (can you 105). But later, this changes into an order: "Can you please take that carton and a / felt tip marker and write down the results" (can you 109). Thus the monologue unravels into a kind of quasi-dialogue with the spectator who responds with expected reactions. With this, of course, the intensity of emotions also gradually increases, or rather, the author's biographic tribulations. At three different points, this goes as far as her actually asking for financial contributions from the spectators. For Semenič, this represents a means to assess the success of her survival techniques. One could also say that at the same time, it allows her to measure the power of the established link between the stage and the audience, i.e., the existence of the autopoietic feedback loop. In her final attempt, she concludes: "well, we're done / i think i did manage to progress a bit / hone my survival tactics some / everything a person needs is, at the end of the / day, an image in gold" (can you 156). And it would appear that it was this kind of contact that the author was looking for the entire time. Not in the sense that she would really be asking for money, but rather for a connection, empathy, understanding: "now you understand me even if i don't speak at all" (Ibid.). 
So the author is the main character in all three plays since these are autobiographical texts performed on stage by the author herself. The connection to the real person and her factual context is thus strongly present, and, correspondingly, so is the representation quality of the text. The plays' predominant form is the monologue, but we can notice a particular development in this respect. While in I, victim, the character is a unified figure whose wholeness is guaranteed by the author and her biography, in do me twice and the second time, her character begins to fall apart. It splits into several communication levels, as it takes on other roles, e.g., the role of the author describing the action in written stage directions, reflecting on her interventions, etc.; first and foremost, she establishes an ever-stronger bond to the reader/spectator. In the second time, the latter is even included in the play as one of its characters which allows for the establishment of the quasi-dialogue. "Quasi" because the You does not have any written lines, and it is clear that this is meant to be the spectator. Of course, the spectator always participates as a communication partner in any performance. Yet, as a rule, this is not in the role of an actual dialogue partner and even less so as a character. But it would seem that it was precisely with the second time that this relationship became crucial to Simona Semenič. As we can discern from some of her later plays, it was here when she started writing and thinking about drama through the spectator's perspective. In such a disposition, the author's position becomes less certain and more dependent on actual readers/spectators. This view implies that in these texts, the legacy of postdramatic theatre is still very much present. It does not, however, in any way diminish the effectiveness of her plays. Quite the contrary, in this way, she is able to address the reader/spectator even more emphatically and immerse them deeper into the action. This way, they also appear to gain more freedom to cocreate the theatre event or at least their own interpretation of it. But to what extent is this freedom real? Is the action completely fragmentary, enticing the spectator to emergence, i.e., perfectly contingent emergence of meanings? To get to the bottom of this question, we must consider the remaining two aspects of the three plays.

Above, we have already given some observations about the dramatic form. The plays move from monologue in I, victim to a kind of dialogue between Simona Semenič and You in the second time, by which we do not mean a real dialogue, of course, since You does not have any lines, they are, however, being addressed all the time and expected to perform specific actions in reaction to the lines spoken by Simona Semenič. At this point, however, we are more interested in how the author shifts between the lyrical, epic and dramatic elements of the text. How does she mix them up? To find this answer, we should follow the hint that she gives in the introduction to the book where she writes: "What you're reading is not a novel, but it's not a theatre text, either. It is what, exactly? It's me, trying to talk to you, it's a warm blankie, it's a sofa" (can you 9).

All three plays are explicitly autobiographical. Their action describes the author's 
life. Even more, it is narrated by the author herself, who also performed the plays herself in the years 2007, 2009 and 2014. Therefore, she talks from and about herself. There is no distance between her and her subject, and this would indicate a lyrical subject. However, she moves closer to a dramatic subject already in do me twice and even more so in the second time, as here Simona Semenič is a character who clearly communicates with a collective receiver addressed as either valued audience or You. The action, however, does not unfold before us in the immediate present time. Instead, it is removed from the subject into a more or less distant past for almost all the time in I, victim and for most of the time in later works. Such a stance, of course, implies an epic approach. Why does all of this matter? This way, the dramatic subject is no longer completely fragmented, as the author's biography guarantees its solidity and coherence. Besides, the very form of performance introduces a strong presence of the real or rather factual world representing an external reference of the action. This referentiality or representation of something that precedes the theatre event itself and is inscribed into the play's text has recently made a noticeable comeback.

It seems interesting that this combination of lyrical, epic and dramatic actually serves as a basis of a text that emphatically creates tension. It elicits strong emotions from the reader/spectator, which range from compassion prevailing in $I$, victim all the way to cooperation, perhaps even resistance to the "riders' syndicate", as the author designates our current social situation, taking a critical stance. In other words, the second time manages to pass a clear political message through a distinctly intimate story and using several procedures from postdramatic theatre.

In his paper "Dramska pisava po postdramskem" (Contemporary Playwrights after the Post-dramatic Turn), Tomaž Toporišič analyses plays by Anja Hilling, Milena Marković and Simona Semenič and detects three approaches to overcoming no-longer-dramatic texts. The impossibility of communication and the deconstruction of body and voice in the case of Anja Hilling, who fragments dialogues and stage directions and mixes them all up; the deconstruction and reconstruction of the representation of reality in plays by Simona Semenič, where we can notice several postdramatic procedures which the author composes into effective critical texts; the contamination with the lyrical and the epic in Milena Marković's work. In Semenič's three plays considered here, it would appear that one can encounter all of these features. We notice the close interweaving of dramatic elements with lyrical and epic ones, a gradual reduction of the division between dialogue and stage directions, and, in the end, fragmentation, involving the spectator into the action proper and the manipulation of emotions, which is supposed to produce meaning. We have already shown to what extent this meaning is consistent and directed from the part of the dramatist in our analysis of the character and monologue/dialogue, which by transitioning from fiction to reality, both approach the dramatic textual form. 
But what about dramatic action? Is the action of the plays completely open, with each recipient inferring its meaning by themselves, or does the text offer some directions which guide its reception? Even though the three texts in question are explicitly fragmentary and appear to be completely open in their meaning, they nevertheless include a strong common thread; the author's biography binds them together. Since all the plays build on Simona Semenič's real life, its understanding is not completely open. Instead, it is built on an emotional response to the author's health issues and financial and creative problems.

Even though the spectator feels compassion towards her, and Semenič with each play involves them more and more into the action itself, one cannot stay at this intimate level. At several points, the author indulges in self-pity and apathy: "i figure the only thing i can try / that i have left / that can save me / are [...] to produce another diagnosis / that i can write a new episode in the victim's self / narrative" (55). Because of this, the anxiety and empathy felt by the receiver most likely relax into a critique of the authority or rather the system, which is the final cause of all of the author's hardships. As she puts it herself: "Using personal incidents, these three texts more or less curse the system in which we're currently living" (10). And the latter is represented by "not the coachmen's syndicate, let's call it the riders' syndicate. Because riders also hold reins in their hands, right?" (12).

I, victim is all about the realisation that the author has been the victim of several absurd medical procedures which endeavoured to deal with her several diagnoses for good (wetting the bed, genital herpes and epilepsy). This victimisation intensifies even further in the book edition, as the author additionally escalates the described situations in her commentaries. Here she mentions the cranial surgery that she underwent in 1991, aged 16, to eliminate her epilepsy for good, as the doctor assured her. Instead, this resulted in even stronger seizures. In her commentary, she reveals to us that the procedure was listed in her neurological results as exploratory craniotomy, that is, a diagnostic procedure that allows insight into the state of the disease and decision regarding treatment. Thus, she concludes: "They played doctors up there. Had they played doctors down there, it would constitute abuse, but because they played up there, it's exploratory craniotomy" (31).

The play do me twice is a so-called iwontreturnthemoney show that the author must do to justify the funding she has received. A fragmentary text combines filled-out forms for public tenders, several additional explanations, pleas and demands included during the selection and funding procedures with a running commentary of the liveaction. It is a kind of collage that forces the recipient into ascribing meaning to it by themselves. However, this is not left entirely to their will, as the play keeps returning to the difficult conditions of cultural production and thus reveals the diverse survival 
tactics in non-governmental production and its actors, primarily oriented towards hyperproduction, and, thus, also negligence and spur-of-the-moment solutions. One such tactic is also the very text/performance in question, which the author does not try to deny:

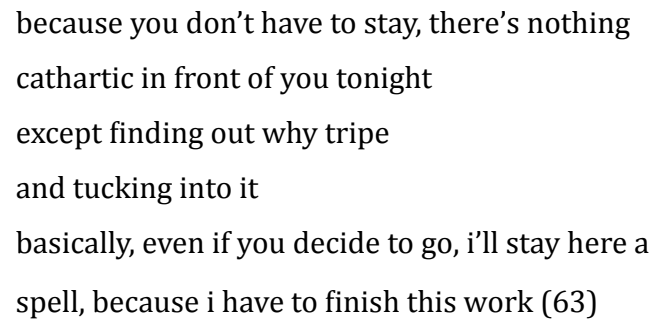

But of course, at the same time, she also skilfully offers the spectator a specific target of their discomfort - the system, as it is the very manner of funding and scantiness thereof that is the reason that she is unable to make a decent living with her work, despite her international success (she ran out of time to prepare the performance due to several engagements abroad and her attendance of the most important festivals in Slovenia) and an indisputable reputation as a playwright.

In the second time, we reach a similar result, albeit through different tactics. The reader/spectator is much more directly involved in the action - they are listed as You in the list of characters, they are asked to assist in measuring the author's blood, to write down the results and to contribute money to increase the author's budget. Besides, Simona Semenič here no longer appears directly as a victim. While the motif is still present first as an echo of the previous two texts and later through all her diagnoses and financial tribulations representing a kind of leitmotif, her attitude here is the polar opposite.

so, victim was a show about some of my

diseases, problems, burdens as i used to call

them in 2007

today i'm not calling them that anymore

today i call them blessings

because i've learned that things that may look

like difficulties are actually gifts

gifts one needs to unwrap in the right way to

become a support and a guideline (115)

Her approach, which used to be based on her victim role and evoking sympathy, has evolved into a more active one. Now she takes charge of her physical condition, 
takes up running, quits smoking ... And, of course, such an active attitude is also reflected in her professional and creative life. The performance the second time describes survival tactics at all levels. Thus, she goes on a strike as a patient "until the riders' syndicate sorts out the public health care system so it is fit for a social state governed by the rule of law" (141). What she is calling for is a transformation of society that would enable everyone to access quality medical care (paid-sick leave for both regularly employed and self-employed), basic financial independence or decent monthly income so that people would not be so stressed out and get sick because of it, and make, e.g., psychotherapy covered by the public health insurance.

At this point, her intimate story turns into a social agenda to which the receiver must take a stance. The conclusion is just as provocative: here, Semenič first puts her body marked by numerous diagnoses and procedures on display to the audience and then dresses it up in gold (from underwear to an evening dress and shoes). This act brings to mind emancipation or the recognition of her value, on the one hand. On the other hand, it recalls prostitution, leads to her final request for contributions. And then come the lines:

well, we're done

i think i did manage to progress a bit

on my survival tactics

everything a person needs is, at the end of the day,

an image in gold (156)

Thus it is clear that as far as their meaning is concerned, these plays are not completely open. Their structure directs the reader/spectator's reception and successfully passes a powerful socially critical message. This message does not function as agitational or didactic. It is based on an honest, intimate story and the skilful manipulation of emotions that the author achieves through several post-dramatic procedures. 
At this point, we can attempt to answer our two starting questions. Are these dramas still based on some external reference? And is this about representation or presence? At first sight, the answer might appear straightforward. Of course, the three texts published in can you hear me? establish some kind of external reference. First and foremost, they refer to the author's biography and her real life. Thus, they directly refer to specific problems within contemporary society, particularly the questions of authority, the functionality of the healthcare system and the area of cultural production.

However, these plays do not depict to the reader/spectator a world that would be separated from them and into which they would supposedly have to immerse themself or reflect upon it. Instead, Semenič keeps involving them in the dramatic action. She demands that the spectator take an active role, be it direct action within the live performance or an emotional response. This response crucially establishes the understanding of the play, which means that a kind of reciprocal functioning of both representation and presentation is at work here. What we saw as an opposition (see Fischer-Lichte) is entering this new cycle as conjunction. The drama is bringing back referentiality and is able to produce a coherent message, while at the same time, it is marked by the experience of the post-dramatic. It no longer counts with the spectator's aesthetic distance and disinterested contemplation in a Kantian sense, nor with distance as a result of the alienation effect (Brecht), which is supposed to keep the spectator within the domain of rational reflection. Instead, it engages the recipient at an emotional level and places them in the position of a co-creator of meaning, even if this participation is to some extent directed. The final result is a strong social criticism, but one built on personal experience which engages the spectator at an emotional level.

To gain deeper insight into Simona Semenič's oscillating between post-dramatic and dramatic writing, we should also analyse her other plays that are, to a greater extent, based on dialogue and stage directions. More importantly, on fictive stories and characters. This analysis, however, reaches beyond the purpose of this paper. The fact is that, similarly to some other European dramatists, Simona Semenič is searching for new forms of writing. Forms that would, besides strongly affecting the spectator and engaging them, also allow for the articulation of clear messages about ourselves and the world in which we live. 
Čičigoj, Katja. "'Naredite lahko karkoli, a biti mora pravilni karkoli.' Odprto delo - tekst kot dogodek." Slovenska dramatika. Edited by Mateja Pezdirc Bartol, Znanstvena založba Filozofske fakultete (Obdobja, 31), 2012, pp. 61-68.

Fischer-Lichte, Erika. Estetika performativnega. Translated by Jaša Drnovšek, Študentska založba, 2008.

Haas, Birgit. "History through the Lens of the Uncertainty Principle: Dea Loher's 'Leviathan'." The Journal of the Midwest Modern Language Association, vol. 39, no. 1, 2006, pp. 73-87.

Lehmann, Hans-Thies. Postdramsko gledališče. Translated by K. J. Kozak, Maska, 2003.

Leskovšek, Nika. "Dramska pisava za današnji čas." Simona Semenič, Tri drame, Beletrina, 2017, pp. 113-141.

Mc Clelland, R. "Between Postdramatic Text and Dramatic Drama: Recent German Playwriting by Lukas Bärfuss and Katja Brunner." Humanities, vol. 9, no. 3, 2020, pp. 1-13. doi.org/10.3390/h9030061

Poschmann, Gerda. Der nicht mehr dramatische Theatertext: Aktülle Bühnenstücke und ihre dramaturgische Analyse, Niemeyer, 1997.

Sarrazac, Jean-Pierre. "Kriza drame." Drama, tekst, pisava, edited by Petra Pogorevc and Tomaž Toporišič, Mestno gledališče ljubljansko, 2008, pp. 13-25.

Semenič, Simona. Can you hear me? Kulturno društvo Integrali, 2019.

—. Tri drame. Beletrina, 2017.

Toporišič, Tomaž. "(Ne več) dramski gledališki tekst in postdramsko gledališče." Primerjalna književnost, vol. 30, no. 1, 2007, pp. 181-189.

-. "(Ne več) dramsko v sodobni slovenski dramatiki (Jovanović, Ravnjak, Potočnjak, Skubic, Semenič)." Slavistična revija, vol. 63, no. 1, 2015, pp. 89-102.

-. "Dramska pisava po postdramskem: Anja Hilling, Milena Marković in Simona Semenič." Slavistična revija, vol. 68, no. 2, 2020, pp. 109-124.

Zajc, Ivana. "Elementi monodrame in avtobiografskosti v besedilih Simone Semenič." Amfiteater, vol. 7, no. 2, 2019, pp. 80-95. 